\title{
Postvaccination SARS-CoV-2 infection among healthcare workers - A Systematic Review and meta-analysis
}

Saurabh Chandan MD¹, Shahab R. Khan MBBS², Smit Deliwala MD³, Babu P. Mohan MD, Daryl Ramai MD4, Ojasvini C. Chandan MD5, Antonio Facciorusso MD PhD6

1. Division of Gastroenterology \& Hepatology, CHI Creighton University Medical Center, Omaha, Nebraska, USA.

2. Department of Medicine, Brigham and Women's Hospital, Harvard Medical School, Boston, Massachusetts, USA.

3. Internal Medicine, Hurley Medical Center, Flint, Michigan, USA

4. Division of Gastroenterology and Hepatology, University of Utah School of Medicine, Salt Lake City, Utah, USA

5. Division of Pediatric Gastroenterology, Hepatology and Nutrition, Children's Hospital of Omaha, Omaha, Nebraska, USA

6. Gastroenterology Unit, Department of Surgical and Medical Sciences, University of Foggia, Foggia, Italy

Corresponding Author:

Saurabh Chandan MD

Assistant Professor of Gastroenterology, CHI Creighton University Medical Center

Creighton University School of Medicine

7710 Mercy Rd. St 2000

Omaha NE 68124 
medRxiv preprint doi: https://doi.org/10.1101/2021.10.04.21264542; this version posted October 7, 2021. The copyright holder for this preprint (which was not certified by peer review) is the author/funder, who has granted medRxiv a license to display the preprint in perpetuity.

All rights reserved. No reuse allowed without permission.

\section{ABSTRACT}

INTRODUCTION: Healthcare workers (HCWs) remain on the front line of the battle against SARSCoV-2 and COVID-19 infection, and are among the highest groups at risk of infection during this raging pandemic. We conducted a systematic review and meta-analysis to assess incidence of postvaccination SARS-CoV-2 infection among vaccinated HCWs.

METHODS: We searched multiple databases from inception through August 2021 to identify studies that reported on incidence of postvaccination SARS-CoV-2 infection among HCWs. Metaanalysis was performed to determine pooled proportions of COVID-19 infection in partially and fully vaccinated individuals.

RESULTS: Eighteen studies with 228,873 HCWs were included in the final analysis. Total number of partially vaccinated, fully vaccinated, and unvaccinated HCWs were 132,922, 155,673 and 17505, respectively. Overall pooled proportion of COVID-19 infections among partially/fully vaccinated and unvaccinated HCWs was 2.1\% (95\% CI 1.2-3.5). Among partially vaccinated, fully vaccinated and unvaccinated HCWs, pooled proportion of COVID-19 infections was 3.7\% (95\% CI 1.8-7.3), 1.3\% (95\% CI 0.6-2.9), and 10.1\% (95\% CI 4.5-19.5), respectively.

DISCUSSION: Our analysis shows the risk of COVID-19 infection in both partially and fully vaccinated HCWs remains exceedingly low when compared to unvaccinated individuals. There remains an urgent need for all frontline HCWs to be vaccinated against SARS-CoV-2 infection.

Keywords: COVID-19, Healthcare workers, vaccine 
medRxiv preprint doi: https://doi.org/10.1101/2021.10.04.21264542; this version posted October 7, 2021. The copyright holder for this preprint (which was not certified by peer review) is the author/funder, who has granted medRxiv a license to display the preprint in perpetuity.

\section{INTRODUCTION:}

Healthcare workers (HCWs) remain on the front line of the battle against SARS-CoV-2 and COVID-19 infection, and through interactions in the workplace related to care and proximity to patients, in addition to household and community interactions, they are among the highest groups at risk of infection during this raging pandemic. ${ }^{1}$ At the peak of the pandemic, a large systematic review of 594 studies noted that 152888 COVID-19 infections and 1413 deaths occurred among HCWs globally. The overall infection and death trends among HCWs followed that of the general population. ${ }^{2}$ More recent estimates suggest that more than 233 million cases of the novel coronavirus have been diagnosed globally, resulting in more than 4 million deaths.

In December 2020, two messenger RNA (mRNA) vaccines, the BNT162b2 vaccine from Pfizer-BioNTech and the mRNA-1273 vaccine from Moderna, were approved by the Food and Drug Administration under Emergency Use Authorization for use among persons 16 years of age or older (for the BNT162b2 vaccine) or among those 18 years or older (for the mRNA-1273 vaccine). Recent data suggests that these vaccines are highly effective under real-world conditions in preventing symptomatic Covid-19 in HCWs, including those at risk for severe Covid-19.3-5 Despite the global push for vaccination, studies show that vaccine hesitancy among HCWs is still common with acceptance rates ranging widely from $27.7 \%$ to $77.3 \%$. Demographic variables such as men, older age and physicians were positive predictive factors, whereas concerns for safety, efficacy and effectiveness and distrust of the government were barriers. ${ }^{6}$

In the recent months, there have been further concerns about emergence of SARS-CoV-2 variants, including variants first reported in the United Kingdom (B.1.1.7), South Africa (B.1.351), 
medRxiv preprint doi: https://doi.org/10.1101/2021.10.04.21264542; this version posted October 7, 2021. The copyright holder for this preprint (which was not certified by peer review) is the author/funder, who has granted medRxiv a license to display the preprint in perpetuity.

All rights reserved. No reuse allowed without permission.

Brazil (P.1), California (B.1.427/B.1.429), and India (B.1.617). 7, 8 As vaccine effective data emerges, we conducted a systematic review and meta-analysis to assess incidence of postvaccination SARS-CoV-2 infection among vaccinated HCWs.

\section{METHODS}

\subsection{Search strategy}

The relevant medical literature was searched by two authors (SC, DR) for studies reporting on the incidence and outcomes of postvaccination COVID-19 infection among HCWs. A systematic and detailed search was run in August 2021 in Ovid EBM Reviews, ClinicalTrials.gov, Ovid Embase (1974+), Ovid Medline (1946+ including epub ahead of print, in-process \& other non-indexed citations), Scopus (1970+), Web of Science (1975+) and Google Scholar. Literature search was performed to include studies published in all languages, and in the case of non-English studies, electronic language translation service was used to convert the text to English. An example search strategy using EMBASE is presented as Supplementary Appendix-1. Articles were included if data with regards to incidence of postvaccination COVID-19 infection was presented. Only cohort studies were eligible for inclusion. All other study designs including, case series of less than 10 patients, case reports, review articles, and guidelines were excluded.

As the included studies were observational in design, the MOOSE (Meta-analyses Of Observational Studies in Epidemiology) Checklist was followed 9 and is provided as Supplementary Appendix-2. PRISMA Flowchart for study selection and PRISMA Checklist ${ }^{10}$ are provided as Supplementary Figure-1 and Supplementary Appendix-2, respectively. Reference lists of evaluated studies were further examined to identify other studies of interest. 
medRxiv preprint doi: https://doi.org/10.1101/2021.10.04.21264542; this version posted October 7, 2021. The copyright holder for this preprint (which was not certified by peer review) is the author/funder, who has granted medRxiv a license to display the preprint in perpetuity.

All rights reserved. No reuse allowed without permission.

\subsection{Data abstraction and quality assessment}

Data on study-related outcomes from the individual studies were abstracted independently onto a standardized form by at least two authors (SC, SRK). Authors (DR, OCC) cross-verified the collected data for possible errors and two authors (SC, SRK) performed the quality scoring independently. We used the Newcastle-Ottawa scale to assess the quality of cohort studies. 11 This quality score consisted of 8 questions, the details of which are provided in Supplementary Table 1.

\subsection{Outcomes assessed}

1. Overall pooled proportion of positive COVID-19 infections in fully, partially, and unvaccinated HCWs

2. Pooled proportion of COVID-19 infections in partially vaccinated HCWs

3. Pooled proportion of COVID-19 infections in fully vaccinated HCWs

4. Pooled proportion of COVID-19 infections in unvaccinated HCWs

5. Pooled proportion of vaccinated HCWs hospitalized for COVID-19 infection

6. Pooled proportion of vaccinated HCWs admitted to ICU for COVID-19 infection

7. Pooled proportion of vaccinated HCWs died from COVID-19 infection

\subsection{Statistical analysis}

We used meta-analysis techniques to calculate the pooled estimates in each case following the methods suggested by DerSimonian and Laird using the random-effects model and results were expressed in terms of pooled proportion (PP) along with relevant $95 \%$ confidence intervals (CIs). ${ }^{12}$ When the incidence of an outcome was zero in a study, a continuity correction of 0.5 was 
medRxiv preprint doi: https://doi.org/10.1101/2021.10.04.21264542; this version posted October 7, 2021. The copyright holder for this preprint (which was not certified by peer review) is the author/funder, who has granted medRxiv a license to display the preprint in perpetuity.

All rights reserved. No reuse allowed without permission.

added to the number of incident cases before statistical analysis. ${ }^{13} \mathrm{~A}$ p-value of $<0.05$ was defined as statistically significant. We assessed heterogeneity between study-specific estimates by using Cochran Q statistical test for heterogeneity, 95\% confidence interval (CI) and the $\mathrm{I}^{2}$ statistics. ${ }^{13-15}$ In this, values of $<30 \%, 30 \%-60 \%, 61 \%-75 \%$, and $>75 \%$ were suggestive of low, moderate, substantial, and considerable heterogeneity, respectively. We assessed publication bias, qualitatively, by visual inspection of funnel plot and quantitatively, by the Egger test. 16 When publication bias was present, further statistics using the fail-Safe $\mathrm{N}$ test and Duval and Tweedie's 'Trim and Fill' test was used to ascertain the impact of the bias. ${ }^{17}$

All analyses were performed using Comprehensive Meta-Analysis (CMA) software, version 3 (BioStat, Englewood, NJ).

\section{RESULTS}

\subsection{Search results and population characteristics}

All search results were exported to Endnote where 22 obvious duplicates were removed leaving 92 citations. Eighteen studies with 228,873 HCWs were included in the final analysis.

Total number of partially vaccinated, fully vaccinated, and unvaccinated HCWs were 132,922, 155,673 and 17505, respectively. A schematic diagram demonstrating our study selection is illustrated in Supplementary Figure 1.

\subsection{Characteristics and quality of included studies}


medRxiv preprint doi: https://doi.org/10.1101/2021.10.04.21264542; this version posted October 7, 2021. The copyright holder for this preprint (which was not certified by peer review) is the author/funder, who has granted medRxiv a license to display the preprint in perpetuity.

All rights reserved. No reuse allowed without permission.

Six studies originated from India, ${ }^{18-23}$ seven from USA, ${ }^{1,24-29}$, two from Israel, ${ }^{30,31}$ and one each from Pakistan, ${ }^{32}$ United Kingdom ${ }^{33}$ and Indonesia. ${ }^{34}$ Further details of patient characteristics, follow up time and type of infection, symptomatic or asymptomatic is presented in Table(s) 1-2

Ten of the included studies were retrospective in design while four were prospective. Based on the New-Castle Ottawa scoring system, all included studies were considered to be of high quality.

\subsection{Meta-analysis outcomes}

1. Overall pooled proportion of positive COVID-19 infections in fully, partially, and unvaccinated HCWs - Across 18 studies, the overall pooled proportion of COVID-19 infections was 2.1\% (95\% CI 1.2-3.5; I² 99.5\%) Figure 1.

2. Pooled proportion of COVID-19 infections in partially vaccinated HCWs - Among partially vaccinated HCWs, across 14 studies, the overall pooled proportion of COVID-19 infections was 3.7\% (95\% CI 1.8-7.3; I² 99.2\%) Figure 2.

3. Pooled proportion of COVID-19 infections in fully vaccinated HCWs - Among fully vaccinated HCWs, across 16 studies, the overall pooled proportion of COVID-19 infections was $1.3 \%$ (95\% CI 0.6-2.9; I2 99.3\%) Figure 3.

4. Pooled proportion of COVID-19 infections in unvaccinated HCWs - Among unvaccinated HCWs, across 8 studies, the overall pooled proportion of COVID-19 infections was 10.1\% (95\% CI 4.9-19.5; I2 99.5\%) Supplementary Figure 2. 
medRxiv preprint doi: https://doi.org/10.1101/2021.10.04.21264542; this version posted October 7, 2021. The copyright holder for this preprint

(which was not certified by peer review) is the author/funder, who has granted medRxiv a license to display the preprint in perpetuity.

All rights reserved. No reuse allowed without permission.

5. Pooled proportion of vaccinated HCWs hospitalized for COVID-19 infection - The overall pooled proportion of both fully and partially vaccinated HCWs hospitalized for COVID-19 infection was 5.7\% (95\% CI 3.5-9.1; I² 48.4\%) Supplementary Figure 3.

6. Pooled proportion of vaccinated HCWs admitted to ICU for COVID-19 infection - The overall pooled proportion of both fully and partially vaccinated HCWs requiring intensive care unit admission for COVID-19 infection was 2.6\% (95\% CI 0.4-15.4; I² 84\%)

Supplementary Figure 4.

7. Pooled proportion of vaccinated HCWs died from COVID-19 infection - The overall pooled proportion of both fully and partially vaccinated HCWs dying for COVID-19 infection was 1.2\% (95\% CI 0.3-5.7; I2 72.6\%) Supplementary Figure 5.

\section{Validation of meta-analysis results}

\subsection{Sensitivity analysis}

To assess whether any one study had a dominant effect on the meta-analysis, we excluded one study at a time and analyzed its effect on the main summary estimate. We found that exclusion of any single study did not significantly affect the primary outcome or influence the heterogeneity.

\subsection{Heterogeneity}

We assessed dispersion of the calculated rates using the $\mathrm{I}^{2}$ percentage values as reported in the meta-analysis outcomes section. We found considerable heterogeneity in our outcomes. This is likely due to variety in the sample size of each individual study, the type of COVID-19 vaccine administered and variation in mean follow up time. 
medRxiv preprint doi: https://doi.org/10.1101/2021.10.04.21264542; this version posted October 7, 2021. The copyright holder for this preprint (which was not certified by peer review) is the author/funder, who has granted medRxiv a license to display the preprint in perpetuity.

\subsection{Publication bias}

Based on visual inspection of the funnel plot for our study outcomes, we found no evidence of publication bias. Quantitative assessment demonstrated an Egger's 2-tailed p-value of 0.4 Supplementary Figure 11(a-c).

\section{DISCUSSION}

Our analysis shows the risk of COVID-19 infection in both partially and fully vaccinated HCWs remains exceedingly low when compared to unvaccinated individuals. We found that while the pooled proportion of unvaccinated HCWs contracting COVID-19 was as high as 47\%, this decreased to $3.7 \%$ for partially vaccinated and $1.3 \%$ for fully vaccinated HCWs. At the time of writing, the COVID-19 pandemic continues to rage across the world and HCWs account for a large number of infected people. ${ }^{35}$ These individuals are both not only victims of the disease, but also potential spreaders. ${ }^{36}$ Therefore, protecting HCWs from SARS-CoV-2 infection would not only be beneficial for themselves, but also for their household contacts and patients. Vaccine acceptance among HCWs and hesitancy remains a concern with studies showing that nurses and assistant nurses were less prone to accept vaccination against COVID-19 than physicians. ${ }^{37}$ Our study is crucial in that it is the first in literature to systematically review and analyze the incidence of COVID-19 infections among partially/fully vaccinated or unvaccinated HCWs.

In December 2020, two messenger RNA (mRNA) vaccines, the BNT162b2 vaccine from Pfizer-BioNTech and the mRNA-1273 vaccine from Moderna, were approved by the Food and Drug Administration under Emergency Use Authorization for use among persons 16 years of age or older (for the BNT162b2 vaccine) or among those 18 years or older (for the mRNA-1273 
medRxiv preprint doi: https://doi.org/10.1101/2021.10.04.21264542; this version posted October 7, 2021. The copyright holder for this preprint (which was not certified by peer review) is the author/funder, who has granted medRxiv a license to display the preprint in perpetuity.

All rights reserved. No reuse allowed without permission.

vaccine). ${ }^{38,} 39$ The U.S. Advisory Committee on Immunization Practices recommended the prioritization of health care personnel during early-phase distribution of these vaccines to ensure that the spread of infection in health care settings was reduced. Vaccination of health care personnel in the United States was initiated in December 2020, and by early March 2021, more than half the frontline health care personnel in the United States had been vaccinated with Covid19 vaccines. ${ }^{40}$ Despite this, vaccine hesitancy in the general population and among HCWs remains a concern. ${ }^{41,42} \mathrm{~A}$ recent review by Biswas et al. reported that the prevalence of COVID-19 vaccination hesitancy worldwide in healthcare workers ranged from 4.3 to as high as $72 \%$, with an average? of $22.51 \%$ across all studies with 76,471 participants. The authors reported concerns about vaccine safety, efficacy, and potential side effects as top reasons for COVID-19 vaccination hesitancy in HCWs. Given the high prevalence of COVID-19 vaccine hesitancy in healthcare workers, communication and education strategies along with mandates for clinical workers should be considered to increase COVID-19 vaccination uptake in these high-risk individuals. ${ }^{43}$ Studies have also shown that vaccination amongst health care workers is associated with a substantial reduction in COVID-19 cases in household contacts consistent with an effect of vaccination on transmission. ${ }^{44}$

At the peak of the pandemic, assessing published data between 01 May to 09 July 2020, researchers found that a significant number of HCW were reported to be infected with COVID-19 during the first 6 months of the COVID-19 pandemic, with a prevalence of hospitalization of $15.1 \%$ and mortality of $1.5 \% .45$ With that in mind, we analyzed the pooled prevalence of COVID-19 infections among HCWs who declined vaccinations and those who either received one or both the vaccines. Our analysis shows that only 5.7\% of vaccinated HCWs required hospitalization for 
medRxiv preprint doi: https://doi.org/10.1101/2021.10.04.21264542; this version posted October 7, 2021. The copyright holder for this preprint (which was not certified by peer review) is the author/funder, who has granted medRxiv a license to display the preprint in perpetuity.

All rights reserved. No reuse allowed without permission.

COVID-19 infection, with 2.6\% needing ICU level-of-care. Mortality associated with COVID-19 infection in partially and/or fully vaccinated HCWs remained low at $1.2 \%$.

There are several strengths to our analysis. First, we conducted a systematic literature search with well-defined inclusion criteria, careful exclusion of redundant studies, inclusion of good quality studies with detailed extraction of data and rigorous evaluation of study quality. All the included studies in our analysis were of high quality. Secondaly, our analysis included outcomes separately for partially and fully vaccinated HCWs. We calculated the pooled proportion of HCWs requiring hospitalization, ICU admissions and also assessed the mortality associated with COVID-19 infection in vaccinated HCWs. Finally, our analysis included studies from different geographical locations, making our results more generalizable and clinically relevant. However, there are also several limitations to this study, most of which are inherent to any meta-analysis. Firstly, at the time of writing and based on our literature search, a total of 18 studies were included in our analysis. As active research continues to be conducted on COVID-19 pandemic, it is possible that we may not have captured all the literature, especially studies not indexed in major databases and/or studies which are published-ahead-of-print. Secondly, we were unable to sub-group our outcomes based on which particular vaccine was administered to the cohort of HCWs. Thirdly, we were unable to determine the mean time to infection occurrence post vaccination, as this information was not consistently reported in the all the studies. There was considerable heterogeneity in our study outcomes likely due to variation in the type of vaccination used and median time to infection occurrence. Lastly, ten of the eighteen studies included in our analysis were retrospective in design which may have resulted in selection bias. 
medRxiv preprint doi: https://doi.org/10.1101/2021.10.04.21264542; this version posted October 7, 2021. The copyright holder for this preprint (which was not certified by peer review) is the author/funder, who has granted medRxiv a license to display the preprint in perpetuity.

All rights reserved. No reuse allowed without permission.

Nevertheless, our study is the first in literature to assess the pooled incidence of postvaccination SARS-CoV-2 infection among health care workers around the world. Our results show decreased incidence of COVID-19 infection as well as decreased incidence of hospitalization, ICU admission and deaths, amongst vaccinated HCWs. Our findings support the urgent need for HCWs to consider getting vaccinated against COVID-19.

Conflicts of interest: None for all the authors

Funding: None

\section{References}

1. Hall VJ, Foulkes S, Saei A, et al. COVID-19 vaccine coverage in health-care workers in England and effectiveness of BNT162b2 mRNA vaccine against infection (SIREN): a prospective, multicentre, cohort study. Lancet 2021;397:1725-1735.

2. Bandyopadhyay S, Baticulon RE, Kadhum M, et al. Infection and mortality of healthcare workers worldwide from COVID-19: a systematic review. BMJ Glob Health 2020;5.

3. Pilishvili T, Gierke R, Fleming-Dutra KE, et al. Effectiveness of mRNA Covid-19 Vaccine among U.S. Health Care Personnel. N Engl J Med 2021.

4. Baden LR, El Sahly HM, Essink B, et al. Efficacy and Safety of the mRNA-1273 SARS-CoV-2 Vaccine. N Engl J Med 2021;384:403-416.

5. Polack FP, Thomas SJ, Kitchin N, et al. Safety and Efficacy of the BNT162b2 mRNA Covid-19 Vaccine. N Engl J Med 2020;383:2603-2615.

6. Li M, Luo Y, Watson R, et al. Healthcare workers' (HCWs) attitudes and related factors towards COVID-19 vaccination: a rapid systematic review. Postgrad Med J 2021.

7. Zhang W, Davis BD, Chen SS, et al. Emergence of a Novel SARS-CoV-2 Variant in Southern California. JAMA 2021;325:1324-1326.

8. Yadav PD, Sapkal GN, Abraham P, et al. Neutralization of variant under investigation B.1.617 with sera of BBV152 vaccinees. Clin Infect Dis 2021. 
medRxiv preprint doi: https://doi.org/10.1101/2021.10.04.21264542; this version posted October 7, 2021. The copyright holder for this preprint (which was not certified by peer review) is the author/funder, who has granted medRxiv a license to display the preprint in perpetuity. All rights reserved. No reuse allowed without permission.

9. Stroup DF, Berlin JA, Morton SC, et al. Meta-analysis of observational studies in epidemiology: a proposal for reporting. Meta-analysis Of Observational Studies in Epidemiology (MOOSE) group. Jama 2000;283:2008-12.

10. Page MJ, McKenzie JE, Bossuyt PM, et al. The PRISMA 2020 statement: An updated guideline for reporting systematic reviews. Int J Surg 2021;88:105906.

11. Stang A. Critical evaluation of the Newcastle-Ottawa scale for the assessment of the quality of nonrandomized studies in meta-analyses. Eur J Epidemiol 2010;25:603-5.

12. DerSimonian R, Laird N. Meta-analysis in clinical trials. Control Clin Trials 1986;7:177-88.

13. Sutton AJ AK, Jones DR, et al. Methods for meta-analysis in medical research. New York: J. Wiley, 2000. 14. Mohan BP, Adler DG. Heterogeneity in systematic review and meta-analysis: how to read between the numbers. Gastrointest Endosc 2019;89:902-903.

15. Higgins J, Thompson SG, Spiegelhalter DJ. A re-evaluation of random-effects meta-analysis. Journal of the Royal Statistical Society: Series A (Statistics in Society) 2009;172:137-159.

16. Higgins JP, Thompson SG, Deeks JJ, et al. Measuring inconsistency in meta-analyses. BMJ 2003;327:557-

60.

17. Duval S, Tweedie R. Trim and Fill: A Simple Funnel-Plot-Based Method of Testing and Adjusting for Publication Bias in Meta-Analysis. Biometrics 2000;56:455-463.

18. Issac A, Kochuparambil JJ, Elizabeth L. SARS-CoV-2 Breakthrough Infections among the Healthcare Workers Post-Vaccination with ChAdOx1 nCoV-19 Vaccine in the South Indian State of Kerala. medRxiv 2021.

19. Pandurangaiah R. Post vaccination COVID-19 infection among health care workers in secondary medical care centre.

20. Sabnis R, Patil A, Shete N, et al. Break-through COVID-19 infection rate with Indian strain in single-center healthcare Workers-A real world data. medRxiv 2021.

21. Vaishya R, Sibal A, Malani A, et al. Post-Vaccination Symptomatic SARS-CoV-2 Infections are Minimal and Non-Serious: An Observational Multicenter Indian Cohort Study of 28342 Healthcare Workers. 2021.

22. Tyagi K, Ghosh A, Nair D, et al. Breakthrough COVID19 infections after vaccinations in healthcare and other workers in a chronic care medical facility in New Delhi, India. Diabetes Metab Syndr 2021;15:1007-1008.

23. Sharma P, Mishra S, Basu S, et al. Breakthrough infection with SARS-CoV-2 and its predictors among healthcare workers in a medical college and hospital complex in Delhi, India. medRxiv 2021.

24. Bouton TC, Lodi S, Turcinovic J, et al. COVID-19 vaccine impact on rates of SARS-CoV-2 cases and post vaccination strain sequences among healthcare workers at an urban academic medical center: a prospective cohort study. medRxiv 2021.

25. Tang L, Hijano DR, Gaur AH, et al. Asymptomatic and Symptomatic SARS-CoV-2 Infections After BNT162b2 Vaccination in a Routinely Screened Workforce. JAMA 2021;325:2500-2502.

26. Jacobson K, Pinsky B, Montez Rath M, et al. Post-Vaccination Severe Acute Respiratory Syndrome Coronavirus 2 (SARS-CoV-2) Infections and Incidence of the Presumptive, B. 1.427/B. 1.429 Variant Among Healthcare Personnel at a Northern California Academic Medical Center. Clin. Infect. Dis 2021;2:1-8.

27. Mathema B, Chen L, Chow KF, et al. Post-vaccination SARS-COV-2 among healthcare workers in New Jersey: a genomic epidemiological study. medRxiv 2021.

28. North CM, Barczak A, Goldstein RH, et al. Determining the Incidence of Asymptomatic SARS-CoV-2 among Early Recipients of COVID-19 Vaccines: A Prospective Cohort Study of Healthcare Workers before, during and after Vaccination [DISCOVER-COVID-19]. Clinical Infectious Diseases 2021.

29. Keehner J, Horton LE, Pfeffer MA, et al. SARS-CoV-2 infection after vaccination in health care workers in California. New England Journal of Medicine 2021;384:1774-1775.

30. Amit S, Beni SA, Biber A, et al. Postvaccination COVID-19 among Healthcare Workers, Israel. Emerg Infect Dis 2021;27:1220-1222. 
medRxiv preprint doi: https://doi.org/10.1101/2021.10.04.21264542; this version posted October 7, 2021. The copyright holder for this preprint (which was not certified by peer review) is the author/funder, who has granted medRxiv a license to display the preprint in perpetuity. All rights reserved. No reuse allowed without permission.

31. Angel $\mathrm{Y}$, Spitzer A, Henig $\mathrm{O}$, et al. Association between vaccination with BNT162b2 and incidence of symptomatic and asymptomatic SARS-CoV-2 infections among health care workers. JAMA 2021.

32. Maroof S, Bakht N, Saleem S, et al. COVID-19 VACCINE BREAKTHROUGH INFECTIONS AMONG HEALTH CARE WORKERS IN MILITARY INSTITUTES OF PAKISTAN-TILL 30TH JUNE 2021. PAFMJ 2021;71:1471-75.

33. Azamgarhi T, Hodgkinson M, Shah A, et al. BNT162b2 vaccine uptake and effectiveness in UK healthcare workers-a single centre cohort study. Nature Communications 2021;12:1-6.

34. Cucunawangsih C, Wijaya RS, Lugito NPH, et al. Post-vaccination cases of COVID-19 among healthcare workers at Siloam Teaching Hospital, Indonesia. International Journal of Infectious Diseases 2021;107:268-270.

35. Nguyen LH, Drew DA, Joshi AD, et al. Risk of COVID-19 among frontline healthcare workers and the general community: a prospective cohort study. medRxiv 2020.

36. Schwierzeck V, König JC, Kühn J, et al. First Reported Nosocomial Outbreak of Severe Acute Respiratory Syndrome Coronavirus 2 in a Pediatric Dialysis Unit. Clin Infect Dis 2021;72:265-270.

37. Gagneux-Brunon A, Detoc M, Bruel S, et al. Intention to get vaccinations against COVID-19 in French healthcare workers during the first pandemic wave: a cross-sectional survey. J Hosp Infect 2021;108:168-173.

38. Oliver SE, Gargano JW, Marin M, et al. The advisory committee on immunization practices' interim recommendation for use of Pfizer-BioNTech COVID-19 vaccine-United States, December 2020. Morbidity and Mortality Weekly Report 2020;69:1922.

39. Food U. Drug Administration Moderna COVID-19 Vaccine, In Vaccines and Related Biological Products Advisory Committee Meeting, 2020.

40. Dooling K, McClung N, Chamberland M, et al. The Advisory Committee on Immunization Practices' interim recommendation for allocating initial supplies of COVID-19 vaccine-United States, 2020. Morbidity and mortality weekly report 2020;69:1857.

41. Lazarus JV, Ratzan SC, Palayew A, et al. A global survey of potential acceptance of a COVID-19 vaccine. Nat Med 2021;27:225-228.

42. Khubchandani J, Sharma S, Price JH, et al. COVID-19 Vaccination Hesitancy in the United States: A Rapid National Assessment. J Community Health 2021;46:270-277.

43. Biswas N, Mustapha T, Khubchandani J, et al. The Nature and Extent of COVID-19 Vaccination Hesitancy in Healthcare Workers. J Community Health 2021.

44. Shah AS, Gribben C, Bishop J, et al. Effect of vaccination on transmission of COVID-19: an observational study in healthcare workers and their households. MedRxiv 2021.

45. Gholami M, Fawad I, Shadan S, et al. COVID-19 and healthcare workers: A systematic review and metaanalysis. Int J Infect Dis 2021;104:335-346.

46. Tsou Y-K, Liu C-Y, Fu K-I, et al. Endoscopic submucosal dissection of superficial esophageal neoplasms is feasible and not riskier for patients with liver cirrhosis. Digestive diseases and sciences 2016;61:3565-3571.

47. Kwon YL, Kim ES, Lee KI, et al. Endoscopic treatments of gastric mucosal lesions are not riskier in patients with chronic renal failure or liver cirrhosis. Surgical endoscopy 2011;25:1994-1999.

48. Choi JH, Kim ER, Min BH, et al. The feasibility and safety of the endoscopic submucosal dissection of superficial gastric neoplastic lesions in patients with compensated liver cirrhosis: a retrospective study. Gut Liver 2012;6:58-63.

49. Ogura K, Okamoto $\mathrm{M}$, Sugimoto $\mathrm{T}$, et al. Efficacy and safety of endoscopic submucosal dissection for gastric cancer in patients with liver cirrhosis. Endoscopy 2008;40:443-5.

50. Soh H, Chun J, Hong SW, et al. Child-Pugh B or C Cirrhosis Increases the Risk for Bleeding Following Colonoscopic Polypectomy. Gut and liver 2020;14:755.

51. Hasan B, Colak Y, Rashid MU, et al. Risk Factors Associated With Postendoscopic Mucosal Resection Bleeding in Patients With Cirrhosis: A Retrospective Multicenter Cohort Study. J Clin Gastroenterol 2021;55:355360. 
medRxiv preprint doi: https://doi.org/10.1101/2021.10.04.21264542; this version posted October 7, 2021. The copyright holder for this preprint (which was not certified by peer review) is the author/funder, who has granted medRxiv a license to display the preprint in perpetuity. All rights reserved. No reuse allowed without permission.

52. Csikesz NG, Nguyen LN, Tseng JF, et al. Nationwide volume and mortality after elective surgery in cirrhotic patients. J Am Coll Surg 2009;208:96-103.

53. Pessione F, Ramond MJ, Peters L, et al. Five-year survival predictive factors in patients with excessive alcohol intake and cirrhosis. Effect of alcoholic hepatitis, smoking and abstinence. Liver Int 2003;23:45-53.

54. Goldacre MJ, Wotton CJ, Yeates D, et al. Liver cirrhosis, other liver diseases, pancreatitis and subsequent cancer: record linkage study. Eur J Gastroenterol Hepatol 2008;20:384-92.

55. Berman K, Tandra S, Vuppalanchi R, et al. Hepatic and extrahepatic cancer in cirrhosis: a longitudinal cohort study. Am J Gastroenterol 2011;106:899-906. 
Study name

Bouton 2021

Tang 2021

Cucunawangsiha 2021

Hall 2021

Issac 2021

Jacobson 2021

Maroof 2021

Mathema 2021

North 2021

Pandurangaiah 2021

Sabnis 2021

Vaishya 2021

Keehner 2021

Tyagi 2021

Sharma 2021

Angel 2021
Statistics for each study

Event rate and $95 \% \mathrm{Cl}$

$\begin{array}{ccccc}\begin{array}{c}\text { Event } \\ \text { rate }\end{array} & \begin{array}{c}\text { Lower } \\ \text { limit }\end{array} & \begin{array}{c}\text { Upper } \\ \text { limit }\end{array} & \text { Z-Value } & \text { p-Value } \\ 0.003 & 0.002 & 0.005 & -24.081 & 0.000 \\ 0.004 & 0.002 & 0.007 & -17.748 & 0.000 \\ 0.013 & 0.007 & 0.021 & -15.655 & 0.000 \\ 0.006 & 0.003 & 0.011 & -15.494 & 0.000 \\ 0.066 & 0.041 & 0.105 & -10.254 & 0.000 \\ 0.002 & 0.001 & 0.002 & -39.594 & 0.000 \\ 0.031 & 0.026 & 0.037 & -37.586 & 0.000 \\ 0.001 & 0.001 & 0.002 & -37.435 & 0.000 \\ 0.002 & 0.001 & 0.005 & -11.183 & 0.000 \\ 0.030 & 0.013 & 0.071 & -7.617 & 0.000 \\ 0.187 & 0.154 & 0.225 & -12.317 & 0.000 \\ 0.050 & 0.048 & 0.053 & -97.860 & 0.000 \\ 0.001 & 0.001 & 0.002 & -40.328 & 0.000 \\ 0.168 & 0.109 & 0.251 & -6.184 & 0.000 \\ 0.189 & 0.148 & 0.239 & -9.535 & 0.000 \\ 0.005 & 0.003 & 0.007 & -27.409 & 0.000 \\ 0.013 & 0.006 & 0.029 & -10.469 & 0.000\end{array}$

Upper

0.007

0.021

0.011

0.037

0.005

0.071

0.002

0.251

0.007

$-10.469$

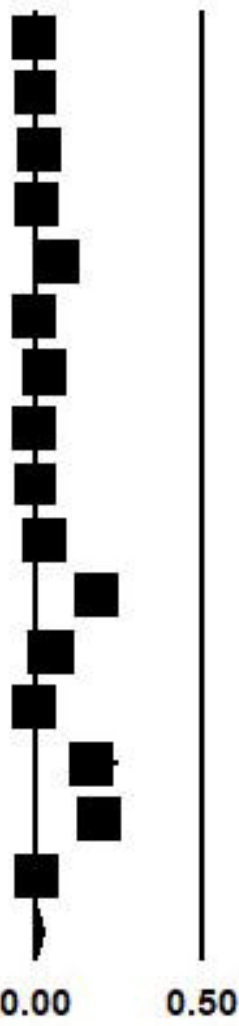

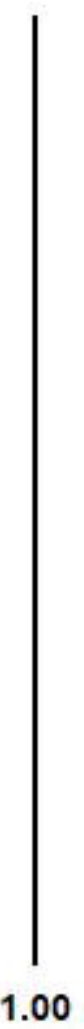


Pooled proportion of COVID-19 infections in partially vaccinated health care workers

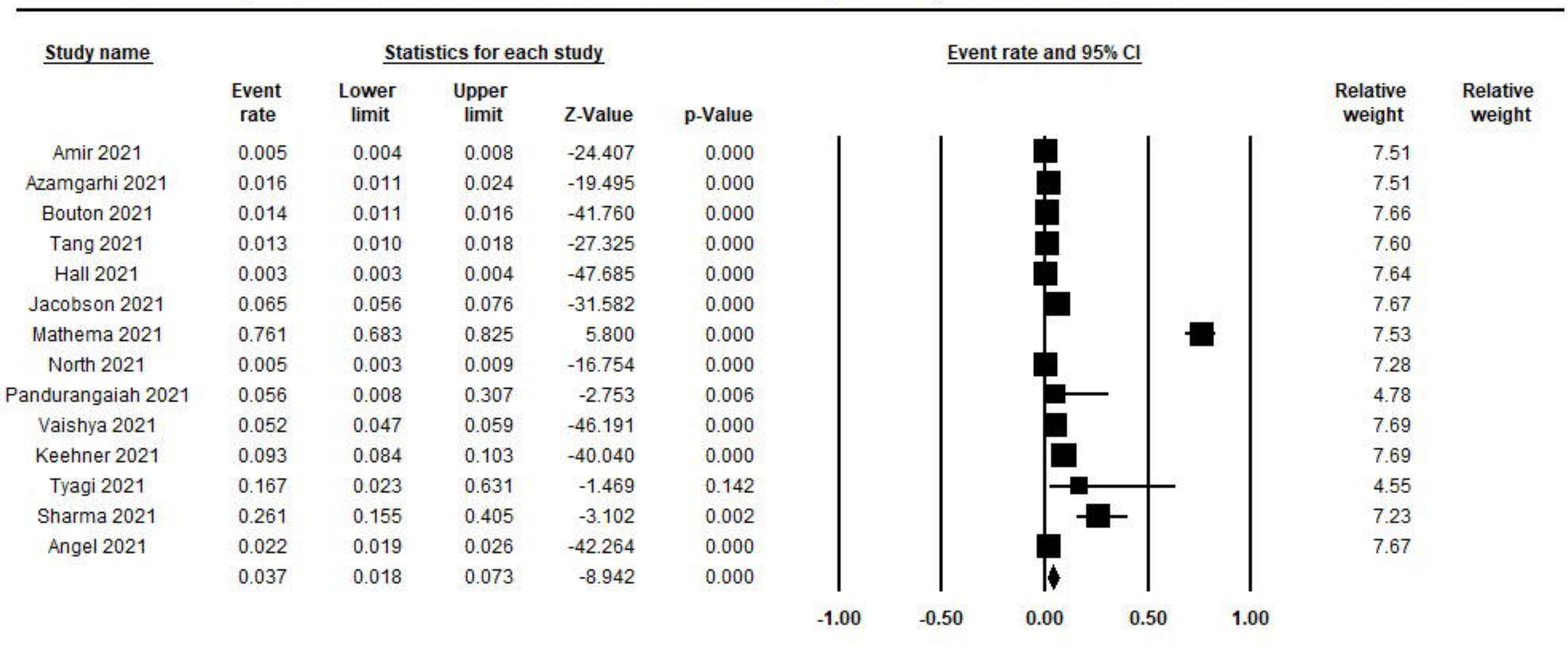


Pooled proportion of COVID-19 positive infections in fully, partially, and unvaccinated health care workers

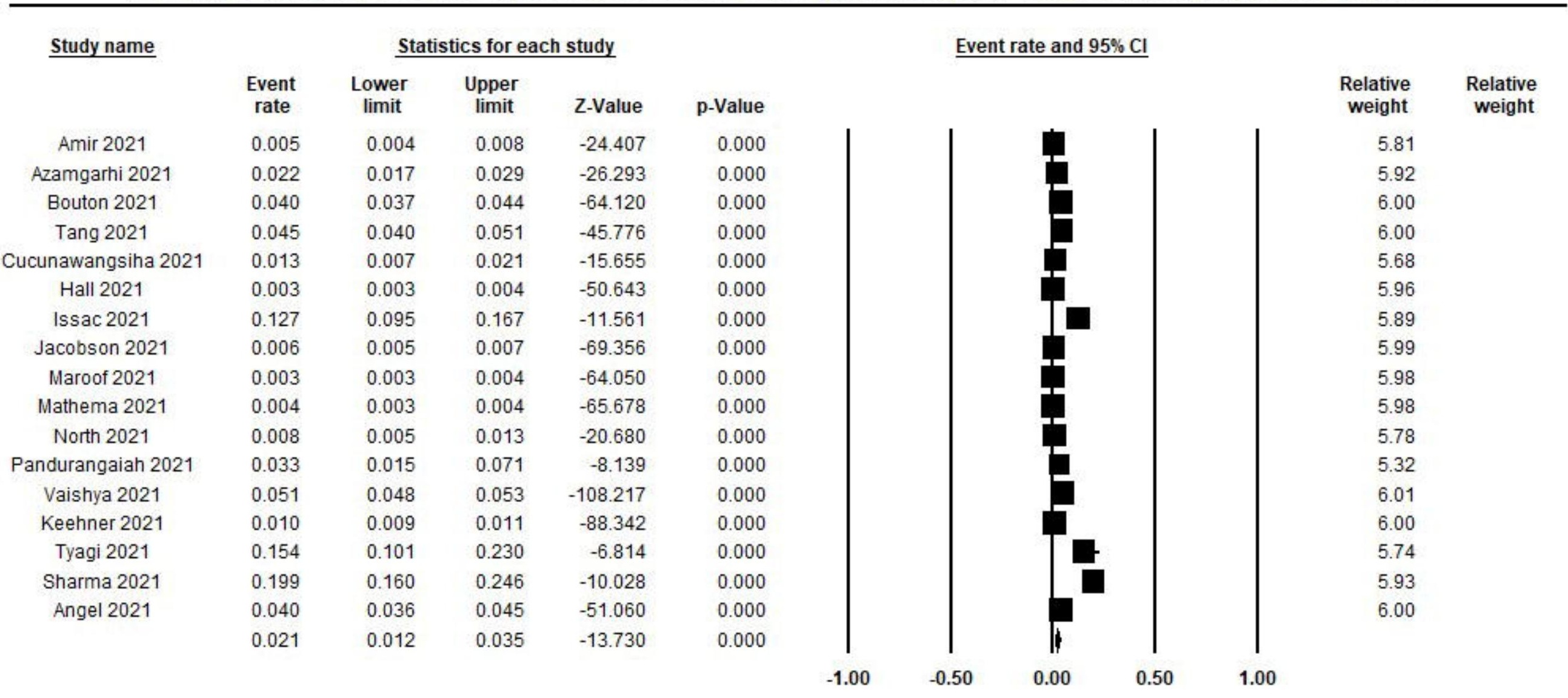

